\title{
KONEKSI PETA GOOGLE MAP DENGAN DATA ASET PEMERINTAH KOTA SEMARANG PADA WEBSITE BPKAD PEMERINTAH KOTA SEMARANG MENGGUNAKAN API GOOGLE MAPS
}

\author{
Endang Lestariningsih ${ }^{1}$, Eka Ardhianto ${ }^{2}$, W.T. Handoko ${ }^{3}$, Edy Supriyanto ${ }^{4}$, Yunny Astutik ${ }^{5}$ \\ ${ }^{2,3}$ Program Studi Teknik Informatika, Fakultas Teknologi Informasi \\ ${ }_{1,4,5}$ Program Studi Sistem Informasi, Fakultas Teknologi Informasi \\ email: ${ }^{1}$ endang_lestariningsih@edu.unisbank.ac.id, ${ }^{2}$ ekaardhianto@edu.unisbank.ac.id, \\ ${ }^{3}$ wthandoko@edu.unisbank.ac.id, ${ }^{4}$ edy_supriyanto@edu.unisbank.ac.id \\ Universitas Stikubank Semarang
}

\begin{abstract}
Abstrak
Kota semarang merupakan daerah yang dikelola oleh pemerintah daerah kota semarang secara mandiri. Salah satu aset yang dikelola adalah aset berupa tanah dan bangunan milik pemerintah serta fasilitas umum yang ada di kota semarang. Aset tanah dan bangunan milik pemerintah kota semarang yang saat ini tercatat dalam Kartu Identitas Barang A terdapat sejumlah 3.092 bidang.
\end{abstract}

Permasalahan yang muncul adalah, bahwa masih ada aset aset milik pemerintah yang tidak diketaui lokasi nya, tidak jelas status penanggung jawabnya dan belum jelas status kepemilikannya. Selain itu petugas yang silih berganti personel, sehingga pengenalan dan pelacakan aset milik pemerintah kota semarang menjadi sulit. Pengelolaan aset tanah oleh pemerintah kota semarang, saat ini dirasa kurang maksimal. Untuk itu perlu dibagun sebuah aplikasi sistem informasi geografi lokasi dan manajemen aset pemerintah kota semarang. Pengkoneksian Application Programming Interface (API) Google Maps pada website BPKAD pemerintah kota semarang akan memberikan informasimengenai lokasi aset tanah dan bangunan milik pemerintah kota semarang pada website googlemap.

Website BPKAD yang terhubung ke googlemap memberikan kemudahan bagi operator untuk mengenali lokasi aset tanah dan bangunan milik pemerintah kota semarang. Keuntungan lain yang didapat yaitu meminimalkan kekeliruan dalam pengelolaan aset tanah dan bangunan.

Kata Kunci : api google maps, peta satelit asset

\section{PENDAHULUAN}

Pengelolaan aset dan pendapatan daerah saat ini dapat dikelola seacara mandiri oleh pemerintah daerah setempat, hal ini berkaitan dengan terbitnya Undang Undang Otonomi Daerah yang mengatur hal tersebut, (krisindarto, 2012[1]). Sebagai pusat ibu kota provinsi jawa tengah, kota semarang merupakan daerah yang dikelola oleh pemerintah daerah kota semarang secara mandiri. Salah satu aset yang dikelola adalah aset berupa tanah dan bangunan milik pemerintah serta fasilitas umum yang ada di kota semarang.

Aset tanah dan bangunan milik pemerintah kota semarang yang saat ini tercatat dalam Kartu Identitas Barang A terdapat sejumlah 3.092 bidang (sundari, 2013,[2]). Aset tersebut dikelolakan oleh Badan Pengeoloaan Aset dan Keuangan Daerah. Aset yang dikelola meliputi aset milik Sekretariat Daerah, Instansi dan Badan diwabah Pemerintah Kota Semarang termasuk Kecamatan dan Kelurahan.

Permasalahan yang muncul adalah, bahwa masih ada aset aset milik pemerintah yang tidak diketaui lokasi nya, tidak jelas status penanggung jawabnya dan belum jelas status kepemilikannya. Hal ini seperti yang di tuliskan oleh krisindarto[1] bahwa penilaian nya tentang pengelolaan aset pemerintah kota semarang belum optimal. Selain itu petugas yang silih berganti personel, sehingga pengenalan dan pelacakan aset milik pemerintah kota semarang menjadi sulit.

Untuk menjawab permasalahan yang muncul, diperlukan sebuah peran dari teknologi informsi yang mana dapat mempermudah dan membatu kegiatan manusia di berbagai bidang, termasuk salah 
satunya untuk memudahkan pengelolaan aset aset yang dimiliki suatu perusahaan, khususnya bagi pemerintah kota semarang, hal ini juga mendukung percepatan terwujudnya semarang sebagai smart city. Untuk itu perlu dibagun sebuah aplikasi sistem informasi geografi lokasi dan manajemen aset pemerintah kota semarang.

Sistem pencatatan data aset pemerintah sudah terdapat pada website yang dimiliki oleh badan pengelolaan keuangan dan aset daerah kota semarang, pada aplikasi ini menambahkan laman untuk melakukan koneksi dengan peta di google map yang mana peta tersebut adalah peta satelit yang dapt digunakan untuk menunjukkan lokasi aset aset milik pemerintah kota semarang.

\section{TUJUAN DAN MANFAAT}

Tujuan dari penelitian ini adalah membuat laman tambahan yang dapat menunjukkan lokasi aset milik pemerinta kota semarang pada peta milik google map. Dan manfaat yang diperoleh adalah adanya kemudahan bagi petugas pengelola dalam melakukan manajemen aset milik pemerintah kota semarang.

\section{TELAAH PUSTAKA}

\section{a. API Google Maps}

Dikutip dari Wikipedia Bahasa Indonesia[3], Google Maps adalah layanan pemetaan web yang dikembangkan oleh Google. Layanan ini memberikan citra satelit, peta jalan, panorama $360^{\circ}$, kondisi lalu lintas, dan perencanaan rute untuk bepergian dengan berjalan kaki, mobil, sepeda (versi beta), atau angkutan umum.

API adalah kependekan dari Application programming interface. Dengan bahasa yang lebih sederhana, API adalah fungsi fungsi pemrograman yang disediakan oleh aplikasi atau provider aplikasi supaya layananan aplikasi tersebut bisa di integrasikan dengan aplikasi yang kita buat. Google maps API adalah fungsi fungsi pemrograman yang disediakan oleh Google maps agar Google maps dapat di integrasikan kedalam Web atau aplikasi yang sedang dikembangkan.

Ada banyak API yang disediakan oleh Google, beberapa diantaranya adalah :

1) Language API : untuk memanfaatkan fitur translation yang dimiliki Google.

2) Earth API : memanfaatkan fitur yang ada pada Google Earth

3) Javascript API : memanfaatkan fitur yang ada pada Google Maps

4) Maps API : : memanfaatkan fitur yang ada pada Google Maps

5) Search API : memanfaatkan fitur pencarian pada Google Search

6) Visualization API : membuat grafik maupun chart dengan Google API

7) YouTube API : memanfaatkan fitur yang adapada YouTube misalnya untuk pencarian video

\section{Pengertian Sistem Informasi Manajemen Lokasi Aset}

Manajemen aset menurut hastings dalam Yaakub [4] adalah serangkaian kegiatan yang terdiri dari indentifikasi aset apa yang dibutuhkan, memperoleh aset, menyediakan logistic dan sistem pendukung pemeliharaan dari aset dan penghapusan atau pembaharuan aset sehingga lebih efektif dan efisien sehingga dapat dikatakan bahwa manajemen aset adalah ilmu dan seni untuk memandu pengelolahan kekayaan.

Dari penjelasan diatas, Sistem Informasi Manajemen Lokasi Aset adalah sebuah mesin atau aplikasi atau kegiatan yang terpadu dengan perangkat lunak dan perangkat keras komputer untuk menyajikan informasi berupa lokasi keberadaan atau lokasi senyatanya aset aset yang dimiliki oleh suatu perusahaan atau organisasi.

\section{Deskripsi Aset Daerah}

Aset daerah merupakan kekayaan daerah yang pada hakikatnya terdiri dari aset bergerak dan tidak begerak. Sebagai contoh aset bergerak, yakni kendaraan dinas, dokumen-dokumen dan lain sebagainya. Sedangkan aset tak bergerak atau tetap yakni lahan, bangunan, dan lain sebagainya. Dalam aspek yang lain, aset pemerintah ini dapat berperan sebagai jaminan pembangunan di daerah.

Berdasarkan Peraturan Pemerintah Nomor 71 Tahun 2010 tentang Standar Akuntasi Pemerintah Aset adalah sumber daya ekonomi yang dikuasai atau dimiliki oleh pemerintah sebagai akibat dari 
peristiwa masa lalu dan dari mana manfaat ekonomi atau sosial di masa depan diharapkan dapat diperoleh, baik oleh pemerintah maupun masyarakat, serta dapat diukur dengan satuan uang, termasuk sumber daya non keuangan yang diperlakukan untuk penyediaan jasa bagi masyarakat umum dan sumber-sumber daya yang dipelihara karena alasan sejarah dan budaya. Pengertian aset secara umum

\section{Deskripsi KIB A}

Menurut Pemendagri No. 17 Tahun 2007, Kartu Inventaris Barang (KIB) adalah kartu untuk mencatat barang - barang inventaris secara tersendiri atau kumpulan/kolektif dilengkapi data asal, volume, kapasitas, merk, type, nilai/harga, dan data lain mengenai barang tersebut yang diperlukan untuk inventarisasi maupun tujuan lain dan dipergunakan selama barang itu belum dihapuskan, KIB terdiri dari :

a. Kartu Inventaris Barang A (tanah). Dan ini adalah data KIB yang saya pergunakan.

b. Kartu Inventaris Baran B (Mesin dan Peralatan).

c. Kartu Inventaris Baran C (Gedung dan Bangunan).

d. Kartu Inventaris Baran D (Jalan, Irigasi dan Jaringan).

e. Kartu Inventaris Baran E (Aset tetap lainnya).

f. Kartu Inventaris Baran F (Konstruksi dalam pengerjaan).

\section{Deskripsi WEB}

Menurut Gregorius [5] "Website adalah kumpulan halaman web yang saling terhubung dan filefilenya saling terkait. Web terdiri dari page atau halaman, dan kumpulan halaman yang dinamakan homepage. Hompage berada pada posisi teratas, dengan halaman-halaman terkait berada di bawahnya. Biasanya setiap halaman di bawah homepage disebut child page, yang berisi hyperlink ke halaman lain dalam web.

Website adalah suatu halaman web yang saling berhubungan yang umumnya berada pada peladen yang sama berisikan kumpulan informasi yang disediakan secara perorangan, kelompok, atau organisasi (Wikipedia)

\section{Alat Alat Pembuat WEB}

\section{a. XAMPP}

XAMPP merupakan salah satu paket installasi Apache, PHP dan MySQL instant yang dapat kita gunakan untuk membantu proses installasi ketiga produk tersebut.

\section{b. MySQL}

MySQL (My Structure Query Language) adalah sebuah program pembuat database yang bersifat open source, artinya siapa saja boleh menggunakannya dan tidak dicekal. MySQL sebenarnya produk yang berjalan pada platform Linux. Selai nitu, MySQL juga merupakan program pengakses database yang bersifat jaringan sehingga dapat digunakan untuk aplikasi multiuser [6].

Kelebihan dari MySQL adalah menggunakan bahasa query standar yang dimiliki SQL (Structure Query Language).SQL adalah bahasa permintaan yang terstruktur yang telah distandarkan untuk semua program pengakses database.Namun MySQL tidak dapat berjalan sendiri tanpa adanya sebuah aplikasi lain(interface).MySQL dapat didukung oleh hamper semua program aplikasi baik yang open source seperti PHP maupun yang tidak, yang ada pada platform Windows seperti Visual Basic, Delphi, dan lain-lain.

\section{c. Macromedia Dreamweaver CS 3}

Macromedia Dreamweaver CS 3 merupakan alat desain web komprehensif yang disukai oleh para profesional web, tapi cukup mudah untuk web designer awal untuk menggunakan juga. Dreamweaver menggunakan WYSIWYG (apa yang Anda lihat adalah apa yang Anda dapatkan) merancang antar muka yang membuat halaman web semudah mengetik dokumen ke dalam pengolah kata.

Program ini juga menawarkan kemampuan untuk bekerja secara langsung dengan kode halaman web bagi mereka yang nyaman dengan HTML. Intuitif menu, panel dan toolbar memungkinkan pemula dan para pakar untuk menambahkan fitur-fitur canggih ke situs Web mereka dengan mudah. 


\section{d. Notepadd ++}

Notepad++ adalah suatu text editor yang berjalan pada Operating System(OS) Windows. Notepad++ disini menggunakan komponen-komponen Scintilla agar dapat menampilkan dan menyunting text dan berkas source code berbagai bahasa pemrograman. Notepad++ didistribusikan sebagai Free Software (gratis) Proyek ini dilayani oleh Sourceforge.net dengan telah diunduh lebih dari 27 juta kali dan dua kali memenangkan penghargaan SourceForge Community Choice Award for Best Developer Tool.

Pengembang dari Notepad++ disini adan Don Ho yang diriliskan pada tanggal 24 November 2003, dengan memiliki license dari GNU General Public License dengan ukuran program yang kecil yaitu 5.5MB. Bahasa pemrograman yang didukung oleh notepad++ adalah bahasa $\mathrm{C}++$ karena fungsifungsinya yang dimasukan kedalam daftar fungsi dan kata-katanya akan berubah sesuai dengan makna kata $\mathrm{C}++$. Berikut ini adalah bahasa pemrograman yang didukung oleh Notepad++ sejak dirilis pada versi 5.9.3 :

- ActionScript, Ada, ASP, Assembler, autoIt

- Batch

- C, C++, C\#, Caml, Cmake, COBOL, CSS

- D, Diff

- Flash ActionScript, Fortran

- Gui4CLI

- Haskell, HTML

- Berkas INI, InnoSetup

- Java, Javascript, JSP

- KiXtart

- LISP, Lua

- Makefile, Matlab, MS-DOS

- NSIS

- Objective-C

- R, Resource file, Ruby

- Shell, Scheme, Smalltalk, SQL

- TCL, TeX

- Pascal, Perl, PHP, Postscript, PowerShell, Properties file, Python

- XML

- YAML

\section{Deskripsi Data Flow Diagram}

Data flow diagram merupakan model dari sistem untuk menggambarkan pembagian sistem ke modul yang lebih kecil. Keuntungan menggunakan DFD adalah pemakai atau user yang kurang menguasai bidang komputer dapat mengerti sistem yang akan dikerjakan. Simbol yang dipakai dalam DFD dapat dilihat pada tabel 1 .

Tabel 1. Simbol pada DFD

\begin{tabular}{|c|c|}
\hline Simbol & Nama \\
\hline & Entitas \\
\hline & Proses \\
\hline & Penyimpanan data \\
\hline & Arus data \\
\hline
\end{tabular}




\section{Macam -macam Data Flow Diagram}

\section{a. Context Diagram}

Context diagram adalah diagram yang terdiri dari suatu proses dan menggambarkan ruang lingkup suatu sistem. Context diagram merupakan level tertinggi dari DFD yang menggambarkan seluruh inputke sistem atau output dar sistem. Diagram ini akan memberi gambaran tentang keseluruhan sistem.

\section{b. Diagram Zero (Overview Diagram)}

Diagram nol / zero adalah diagram yang menggambarkan proses dari data flow diagam. Diagram zero memberikan pandangan secara menyeluruh mengenai sistem yang ditangani, menunjukkan tentang fungsi - fungsi utama atau proses yang ada, aliran data, dan external entity. Pada level ini sudah digambarkan adanya data store yang digunakan. Untuk proses yang tidak rinci, akan dijelaskan pada level selanjutnya. Keseimbangan input dan output (balancing) antara diagram zero dengan context diagram harus tetap terpelihara.

\section{c. Diagram Rinci (Level Diagram)}

Diagram rinci adalah diagram yang menguraikan proses apa yang ada dalam diagram zero atau diagram level diatasnya.

\section{d. Entity Relationship Diagram (ERD)}

ERD adalah suatu model jaringan yang menggunakan susunan data yang disimpan dalam sistem secara abstrak (Ladjamudin, 2005). ERD digunakan oleh professional sistem untuk berkomunikasi dengan pemakai eksekutif tingkat tinggi dalam suatu organisasi. Selain itu, ERD memperlihatkan hubungan antar data storepada DFD. ERD mempunya 4 elemen, yaitu :

1) Himpunan entitas (entity), yaitu sesuatu (apa saja) yang ada didalam sistem, nyata maupun abstrak dimana data tersimpan atau dimana terdapat data. Entitas dikelompokkan menjadi empat jenis nama, yaitu orang, benda, lokasi, kejadian (terdapat unsur waktu didalamnya).

2) Himpunan relasi (relationship), yaitu hubungan alamiah yang terjadi diantara entitas.

3) Atribut, yaitu sifat atau karakteristik dari tiap entitas maupun tiap relationship.

4) Garis penghubung (link), yaitu penghubung antar elemen.

Untuk lebih jelasnya dapat dilihat pada tabel 2.

Tabel 2. Elemen ERD

\begin{tabular}{|c|c|}
\hline & Nama \\
\hline & Himpunan entitas (entity) \\
\hline & Himpunan relasi (relationship) \\
\hline & Atribut \\
\hline & Garis penghubung (link) \\
\hline
\end{tabular}

\section{METODE PENELITIAN}

Metode penelitian yang digunakan adalah melakukan pengembangan perangkat lunak dengan menggunakan model prototiping. Model pengembangan perangkat lunak dengan model prototipe ini akan menghasilkan sebuah aplikasi dalam bentuk prototipe sebelum aplikasi tersebut memasuki tahap design. Dalam fase ini, prototype yang telah dirancangakan dievaluasi. Tahap ini akan terus menerus 
diulang sampai aplikasi benar benar sesuai dengan keinginan. Apabila prototype telah selesai, maka tahapan aplikasi akan kembali berlanjut ketahap design. Gambar 1 menjelaskan bagaimana urutan proses pengembangan perangkat lunak dengan model prototype [6].

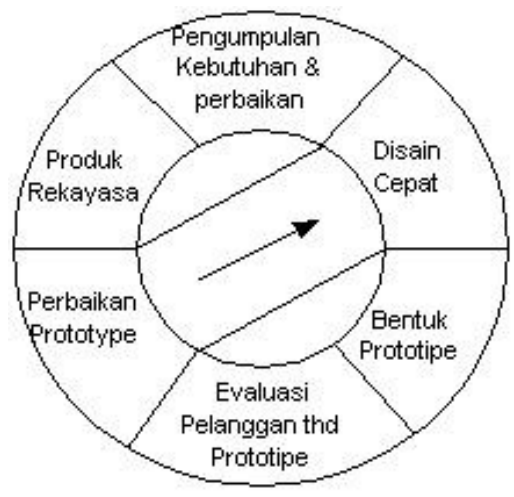

Gambar 1. Prototyping Method

(Pressman, Roger S.,2002)

\section{HASIL DAN PEMBAHASAN}

\section{a. Bahan Penelitian}

Bahan penelitian yang digunakan dalam penelitian ini adalah bahan yang nantinya digunakan sebagai bahan input, proses alur bisnis dan output. Adapun bentuk bahan inputan yang digunakan adalah : website BPKAD pemerintah kota semarang. Sedangkan bahan untuk proses alur bisnis adalah menggunakan menambahkan database dan tabel untuk mengkoneksikan antara data kartu identitas barang pada website BPKAD kota semarang dengan menambahkan halaman yang memiliki koneksi ke website google maps

\section{1). Bahan Input}

Bahan inputan yang dimaksudkan didalam penelitian ini adalah data pada website BPKAD pemerintah kota semarng. Seperti terlihat pada gambar 2.

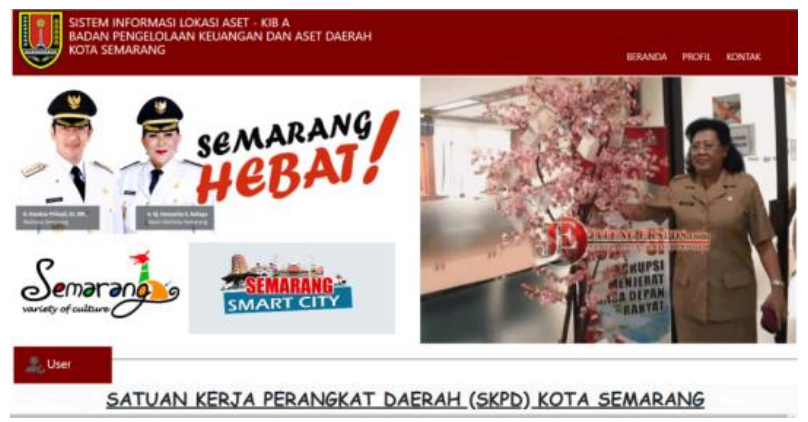

Gambar 2. Data input

\section{2). Output}

Output merupakan hasil keluaran dari data data yang terkumpul dan sudah diolah. Bentuk output atau keluaran dari proses adalah halaman tambahan yang telah terkoneksi dengan website BPKAD kota semarang yang dapat menunjukkan lokasi aset milik pemerintah kota semarang pada website google map.

\section{b. Analisa Sistem Berjalan}

Dalam proses yang sedang berjalan, saat ini data aset yang tersimpan dalam website BPKAD kota semarang masih berupa data saja dalam bentuk tabel tanpa terlihat lokasi sebenarnya aset pada peta berada di sebelah mana, sehingga bagi petugas pengelola aset cukup menyulitkan untuk mengetahui 
bagaimana cara petugas jika ingin melakukan survey lokasi dan mengetahui dimana letak lokasi aset secara persisnya pada peta, sehingga diperlukan sebuah halaman baru yang mampu menunjukkan letak aset barang yang terdapat pada website BPKAD kota semarang pada peta satelit melalui google maps, sehingga akan mempermudah petugas dalam melakukan majanemen aset milik pemerintah kota semarang.

\section{c. Rancangan Sistem}

Bentuk rancangan penambahan koneksi website BPKAD kota semarang ini adalah : 1. Menambah filed untuk koordinat peta (langitude dan latitude), 2. Membuat antarmuka tambahan yang menghubungkan data aset ke lokasi titik koordinnat pada peta google maps. Gambar 5.2 menggambarkan bentuk bagan rancangan sistem yang dibauat.

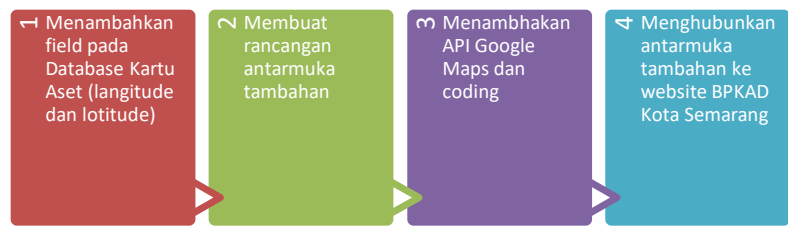

Gambar 3. Bagan rancangan sistem penambahan halamana website BPKAD Kota Semarang

Dari gambar 3 dapat dijelaskan bahwa bentuk rancangan kerja adalah menambahkan field langitude dan lotitude, merancang antarmuka, menambahkan coding dan API goggle maps dan menghubungkan halaman tambahan ke website BPKAD Kota Semarang.

\section{d. Hasil Implementasi}

\section{1) Menambahkan Field pada Database}

Gambar 5.3 adalah bentuk hasil penambahan field longitude dan latitude pada database website BPKAD kota semarang. Fungsi dari field tersebut adalah menyimpan data koordinat lokasi aset tanah dan bangunan di kota semarang. Untuk mengisikan, petugas perlu mendeteksi terlebih dahulu nilai koordinat melalui website googlemaps kemudian mengisikan ke dalam database BPKAD kota semarang.

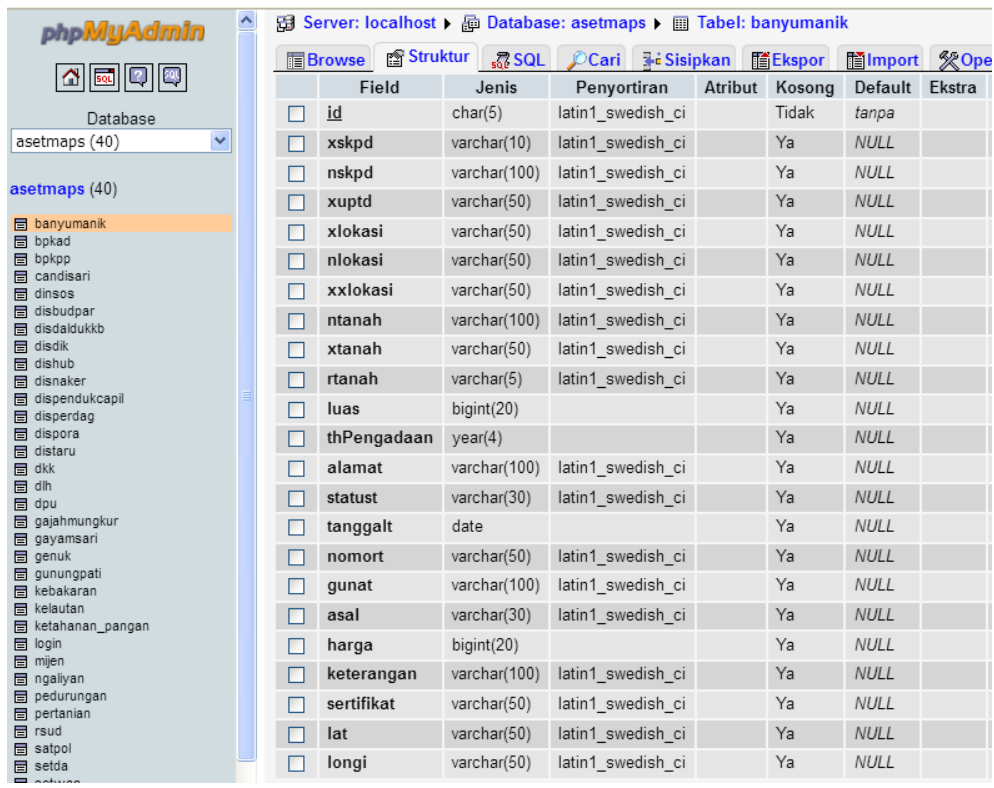

Gambar 4 struktur tabel dan database yang telah ditambahkan field (lagitude dan latitude) 


\section{2) Membuat rancangan Antarmuka tambahan}

\begin{tabular}{||l|l|}
\hline Logo & Peta google map \\
\hline Data & \\
detil & \\
aset & \\
tanah / & \\
\hline
\end{tabular}

Gambar 5 Rancangan Antarmuka Informasi Aset Tanah dan Bangunan

Rancangan antarmuka, diperlihatkan pada gambar 5 yaitu gambar rancangan antarmuka yang nantinya akan berisi data informasi aset tanah dan bangunan dan peta googlemaps yang menunjukkan lokasi aset bangunan atau tanah yang dimaksud. Sdeangkan gambar 6 adalah menunjukkan gambar hasil setelah dijalankan.

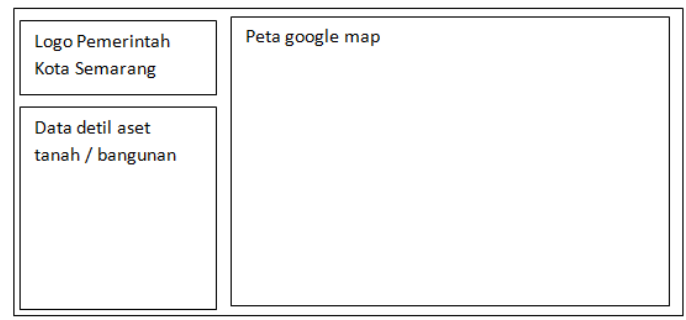

Gambar 6 Rancangan Antarmuka Peta Google Maps Lokasi Aset Bangunan
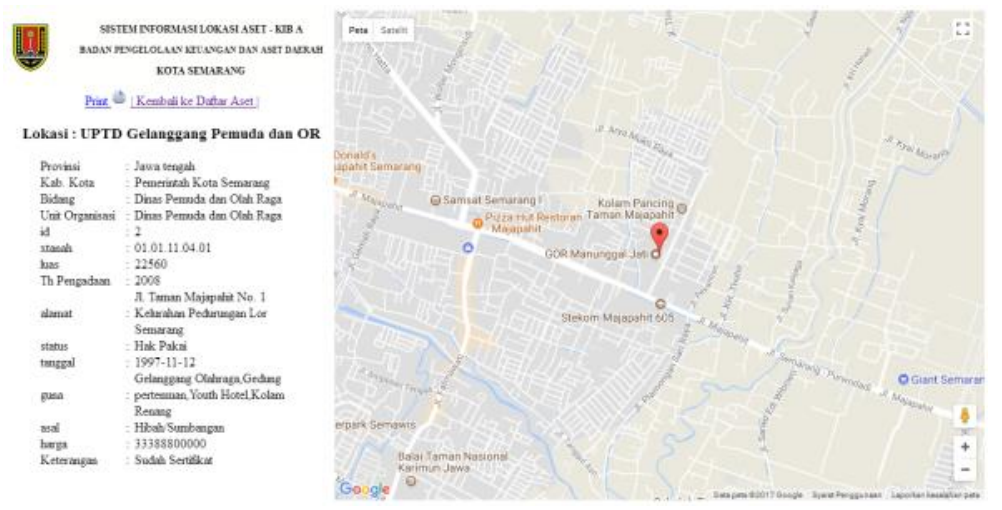

Gambar 7 Halaman aset yang terkoneksi dengan peta satelit

\section{3) Menambahkan API GoogleMap pada sourcecode}

Gambar 5.5 adalah potongan script yang digunakan untuk menampilkan peta lokasi pada google maps. Pada script ini terdapat tiga bagian yang perlu disesuaikan sehingga halaman web dapat memuat peta googlemap dan menunjukkan lokasi pada peta. Pada awal script perlu dideklarasikan source link site yang akan diakses yaitu googleapis.com kemudian diisikan kode api google maps yang kita dapatkan setalah mendaftar dan meminta kode google dari sebsite tersebut. Selanjutkan pada tahap kedua menambhakan script java berupa : fucntion initialize, function bindInfo dan function setMarker. Function setMarker digunakan untuk mengambil model tanda lokasi pada peta google, sedangkan function initialize digurnakan untuk : menseting jarak visual peta, menempatkan marker pada lokasi sesuai dengan field langitude dan latitude, menambahkan info kedalam peta berupa beberapa data dari aset, sedangkan fungtion bindInfo digunakan untuk memberikan efek saat marker diklik sehingga memberikan informasi data aset. 


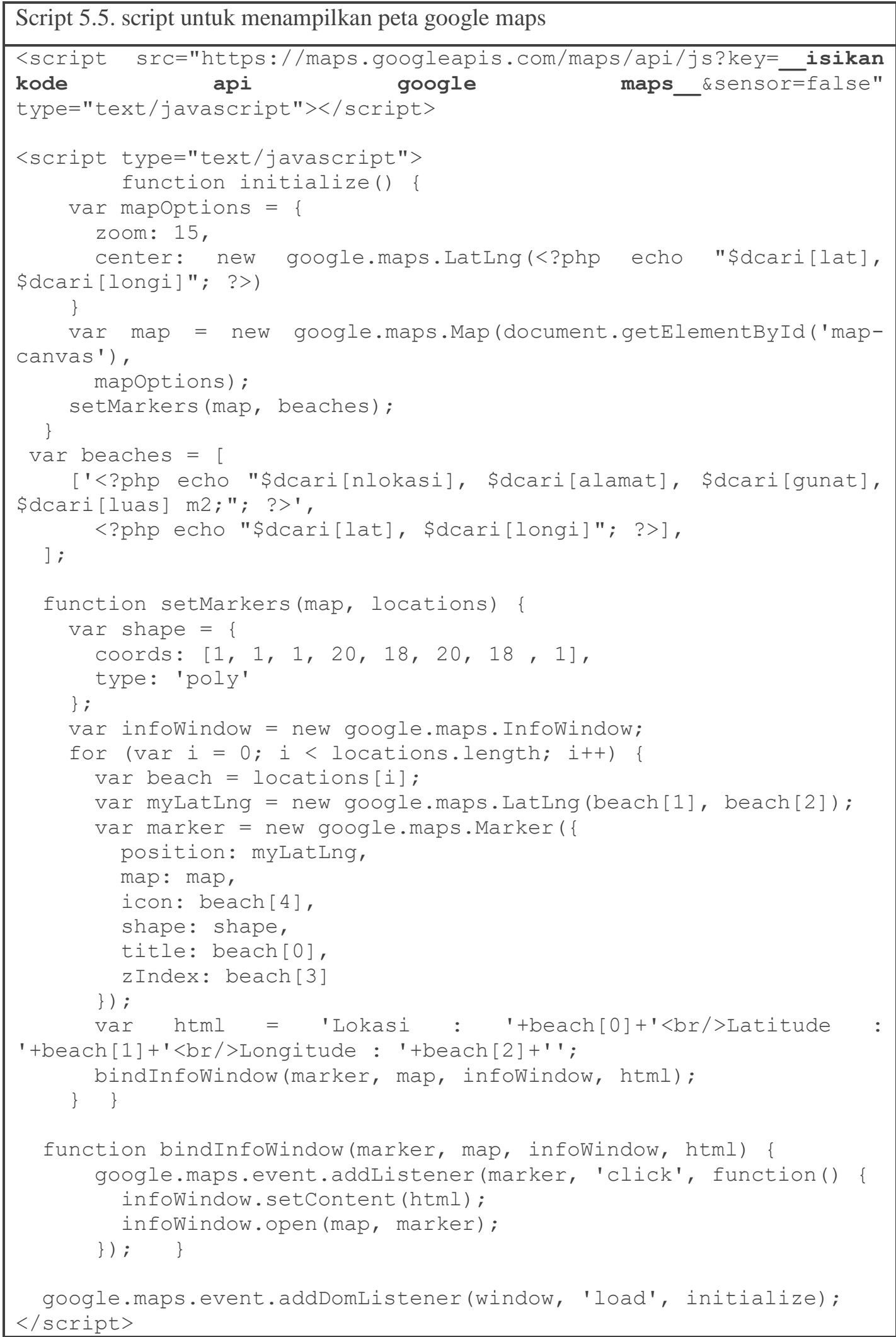

\section{4) Menghubungkan halaman tambahan dengan website BPKAD Kota Semarang}

Pada website BPKAD kota semarang, halaman pertama yang tampil adalah halaman index yang memuat beberpa satuan kerja perangkat daerah dibawah pemerintah Kota Semarang yang memiliki aset seperti terlihat di gambar 8 pada daftar aset tersebut terdapat tombol "lihat peta" yang digunakan untuk 
menghubungkan halaman website BPKAD kota Semarang dengan halaman tambahan yang berisi peta lokasi simana aset berada. Seperti pada gambar 9 .

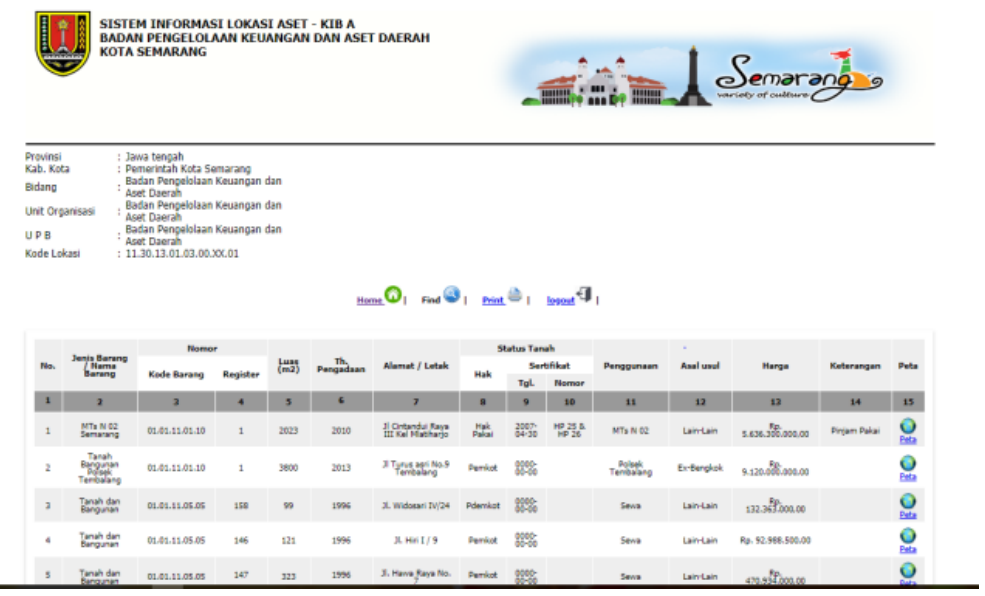

Gambar 8. halaman data aset BPKAD Kota Semarang
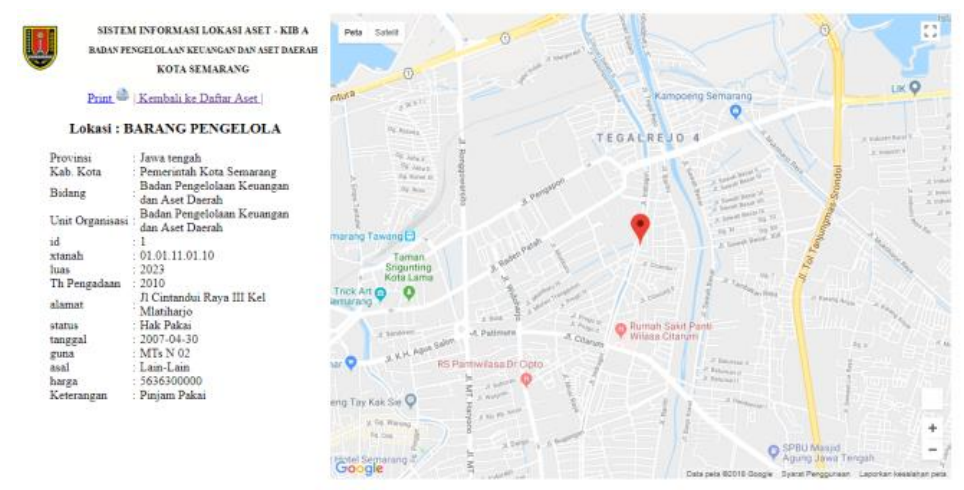

Gambar 9. Halaman tambahan yang telah dihubungkan dengan halaman website BPAKD Kota Semarang

\section{KESIMPULAN}

\section{a. Kesimpulan}

Dari proses penelitian yang dilakukan dapat ditarik kesimpulan bahwa penambahan koneksi dengan peta google maps dengan halaman pada website BPKAD kota semarang memberikan dampak : meningkatkan efesiensi dan efektivitas kerja pegawai, dari sisi penyimpanan data lebih terjamin dan lebih hemat karena tidak menggunakan proses manual, mempersingkat waktu training bagi pegawai baru karena penggunaannya yang mudah dan tidak memerlukan waktu lama dan membantu transparasi data antara pemerintah daerah dan masyarakat karena masyarakat juga dapat mengakses sistem walau hanya melihat daftar aset.

\section{b. Saran}

1) Perlu ditambahkan fitur back-up data untuk menanggulangi kerusakan data

2) Perlu ada fitur log aktifitas pengguna baik sebagai administrator dan guest/tamu.

3) Perlu dikembangkan untuk menjadi perangkat berbasis android.

\section{DAFTAR PUSTAKA}

[1] Krisindarto, A., 2012, Pengelolaan Aset Tanah Milik Pemerintah Kota Semarang, Jurnal Pengembangan Wilayah \& Kota, volume 8(4) : hal. 403-411, Biro Penerbit Planologi Undip, Universitas Diponegoro, Semarang.

[2] Sundari, M., dan Maarif, S., 2013, Optimalisasi Pemanfaatan Tanah Aset Pemerintah Kota Semarang di Kecamatan Banyumanik, Jurnal Pengemangan Wilayah \& Kota, volume 9(2) : hal. 163-173, Biro Penerbit Planologi Undip, Universitas Diponegoro, Semarang. 
[3] https://id.wikipedia.org /wiki/ Google_Maps, diakses : 20 november 2017.

[4] Yaakub, S., dan Devitra., J., 2017, Analisis Pemodelan Sistem Informasi Manajemen Aset Berbasis Web Pada Politeknik Jambi, Jurnal Manajemen Sistem Informasi, volume 2 No. 3, September 2017, hal. 610-628, ISSN : 2540-8011

[5] Agung, Gregorius, (2000). Membuat Hompage Interaktif dengan CGI/Perl. Jakarta: PT. Elex Media Komputindo

[6] Bunafit Nugroho. 2004. PHP dan MYSQL dengan editor Dreamweaver MX. Yogyakarta : ANDI Yogyakarta

[7] Pressman, Roger S. 2002." Rekayasa Perangkat Lunak (Pendekatan Praktis).” Yogyakarta : Andi.

[8] Fahmi, A., dan Sugiarto, E., 2015, Aplikasi Sistem Informasi Geografis Manajemen Aset Wakaf, Prosiding SNATIF ke-2 tahun 2015, ISBN : 978-602-1180-21-1

[9] Kurniawan, Y., 2012, Rancang Bangun Sistem Informasi Geografis Untuk Pemetaan Aset Daerah dengan Pemanfaatan Google API, Prosiding Seminar Nasional Manajemen Teknlogi XVI, Program Studi MMT-ITS, Juli 2012. ISBN : 978-602-97491-4-4 